Vodermaier, H. C., Gieffers, C., Maurer-Stroh, S., Eisenhaber, F., and Peters, J. M. (2003). TPR subunits of the anaphase-promoting complex mediate binding to the activator protein CDH1. Curr. Biol. 13, 1459-1468.

Wu, H., Lan, Z., Li, W., Wu, S., Weinstein, J., Sakamoto, K. M., and Dai, W. (2000). p55CDC/ hCDC20 is associated with BUBR1 and may be a downstream target of the spindle checkpoint kinase. Oncogene 19, 4557-4562.

Wu, M., and Gerhart, J. (1991). Raising Xenopus in the laboratory. Methods Cell Biol. 36, 3-18.

Yamano, H., Kominami, K., Harrison, C., Kitamura, K., Katayama, S., Dhut, S., Hunt, T., and Toda, T. (2004). Requirement of the SCFPop1/Pop2 ubiquitin ligase for degradation of the fission yeast S phase cyclin Cig2. J. Biol. Chem. 279, 18974-18980.

Yoon, H. J., Feoktistova, A., Wolfe, B. A., Jennings, J. L., Link, A. J., and Gould, K. L. (2002). Proteomics analysis identifies new components of the fission and budding yeast anaphase-promoting complexes. Curr. Biol. 12, 2048-2054.

\title{
[17] Purification and Assay of the Budding Yeast Anaphase-Promoting Complex
}

By Lori A. Passmore, David Barford, and J. Wade Harper

\section{Abstract}

The anaphase-promoting complex (APC) is a central regulator of the eukaryotic cell cycle and functions as an E3 ubiquitin protein ligase to catalyze the ubiquitination of a number of cell cycle regulatory proteins. The APC contains at least 13 subunits in addition to two activator subunits, Cdc20 and Cdh1, that associate with the APC in a cell cycle-dependent manner. This chapter describes methods for preparation and assay of the APC from Saccharomyces cerevisiae. Highly active APC is purified from cells expressing Cdc16 fused with a tandem affinity purification (TAP) tag. Enzymatically active APC is achieved upon addition of recombinant Cdc20 or Cdh1 together with E1, Ubc4, ATP, and ubiquitin. Activity assays toward several endogenous substrates, including Clb2 and Pds1, are described. In addition, methods for observation of APC-coactivator and APC-substrate complexes by native gel electrophoresis are described.

\section{Introduction}

Progression through the mitotic phase of the cell cycle is regulated by ubiquitin-mediated proteolysis of regulatory proteins and by the periodic activity of the major mitotic kinase Cdk1/cyclin B. Ubiquitin-mediated proteolysis controls several transitions during mitosis, including chromosomal 
segregation, reorganization of the mitotic spindle, and exit from mitosis, in part through the ubiquitination of B-type cyclins. A major ubiquitin ligase controlling mitosis is the anaphase-promoting complex, which is also referred to as the cyclosome (reviewed in Harper et al., 2002; Peters, 2002). The APC is composed of at least 13 core subunits. Activation of the APC involves phosphorylation by cyclin-dependent kinases (Cdks) (Golan et al., 2002; Kotani et al., 1998; Kramer et al., 2000; Rudner and Murray, 2000), as well as association with two coactivators, Cdc20 and Cdh1, which bind the APC in a cell cycle-dependent manner (Fang et al., 1998; Kramer et al., 2000; Visintin et al., 1997; Zachariae et al., 1998a). Substrate specificity is thought to be largely dictated by Cdc20 and Cdh1 (Burton and Solomon, 2001; Hendrickson et al., 2001; Hilioti et al., 2001; Pfleger and Kirschner, 2000; Pfleger et al., 2001; Visintin et al., 1997). In budding yeast, Cdc20 is largely responsible for ubiquitination of Pds1 at the metaphase-anaphase transition, whereas Cdh1 is largely responsible for ubiquitination of B-type cyclins, Cdc5, Hsl1, and Cdc20 itself (Harper et al., 2002; Peters, 2002). There is some evidence that the coactivators may bind APC substrates directly (Burton and Solomon, 2001; Hilioti et al., 2001; Pfleger and Kirschner, 2000; Pfleger et al., 2001), with the assistance of the Doc1/Apc10 subunit (Passmore et al., 2003). However, the precise function of the coactivators is unclear.

While much of our understanding of the components and function of the APC has derived from budding and fission yeast systems, only recently has budding yeast APC activity toward full-length natural substrates been reconstituted in vitro. This is in stark contrast to the situation with Xenopus and mammalian APC complexes, where activity assays against multiple substrates have been available for some time (Aristarkhov et al., 1996; King et al., 1995). This chapter describes methods for purification and assay of the budding yeast APC. In addition, it describes methods for visualization of APC complexes with both substrates and coactivator subunits using native gel analysis.

\section{Overview of Assay Development}

Enzymatic analysis of APC activity requires several components: (1) purified APC, (2) coactivator subunits Cdc20 or Cdh1, (3) E1 ubiquitinactivating enzyme, (4) an appropriate E2 ubiquitin-conjugating enzyme (UBC), and (5) appropriate substrates, in addition to ubiquitin and ATP. In the case of vertebrate APC, APC core complexes can be purified by conventional column chromatography to yield a preparation that is active in the presence of added Cdc20 or Cdh1. However, most frequently, APC core complexes are purified using a single-step immunopurification procedure involving anti-Cdc27 or anti-Cdc16 antibodies as an affinity reagent. 
The ability to selectively tag yeast genes with epitope tags has made it possible to generate high-purity budding yeast APC using tandem affinity purification (TAP) wherein the epitope tag is fused to the $\mathrm{C}$ terminus of Cdc16, a core APC subunit (Carroll and Morgan, 2002; Passmore et al., 2003; Zachariae et al., 1996). As described later, current procedures employ a TAP tag composed of the IgG-binding domain of protein A, one or more TEV protease cleavage sites, and a small peptide capable of binding to calmodulin in a calcium-dependent manner. Purification of Cdc16-TAP and its associated APC subunits involves (1) affinity chromatography on IgG Sepharose beads, (2) cleavage of bound fusion proteins with TEV protease, (3) capture of the Cdc16-calmodulin binding peptide by affinity chromatography on calmodulin beads in the presence of calcium, and (4) elution of the APC complex from the calmodulin beads in the presence of EGTA (Fig. 1B). Such preparations support the ubiquitination of fulllength native yeast APC substrates (including Pds1, Hsl1, and Clb2), as well as an artificial substrate composed of residues 12-91 of sea urchin cyclin B, when combined with recombinant $\mathrm{Cdc} 20$ or Cdh1 as the activating subunit (Carroll and Morgan, 2002; Passmore et al., 2003). An alternative approach employing a single-step purification of Cdc16-HA using an anti-HA affinity resin has also been reported (Charles et al., 1998). The following section describes the purification and assay of budding yeast APC using the TAP-tag approach.

\section{Construction of Yeast Strain Expressing Cdc16-TAP}

We have used polymerase chain reaction (PCR)-based gene targeting with a modified version of the pFA6a-kanMX6 vector series (Fig. 1A) (Wach et al., 1998) to fuse the coding region for a C-terminal affinity purification tag onto the chromosomal copy of an APC gene (Passmore, 2003; Passmore et al., 2003). Because the gene is tagged at its $3^{\prime}$ end, the promoter region is not disrupted and expression of the fusion protein should be equivalent to that in wild-type yeast. This is important for the modification of APC subunits, as many of them are essential for growth and a change in their endogenous expression levels may be toxic. We use the protease-deficient yeast BJ2168 (MATa leu2 trp1 ura3-52 pep4-3 prc1-407 prb1-1122 gal2; ATCC 208277) (Jones, 1977; Zubenko et al., 1980) for gene targeting and protein purifications. The CDC16 gene was tagged because, in previous studies, it had been tagged with at least nine Myc epitopes without affecting APC function (Zachariae et al., 1996) and an immunoprecipitation of APC from a CDC16-9MYC yeast strain had provided enough protein for analysis of its subunits by mass spectrometry (Zachariae et al., 1998b). These factors indicated that the $\mathrm{C}$ terminus of Cdc16p is 
A

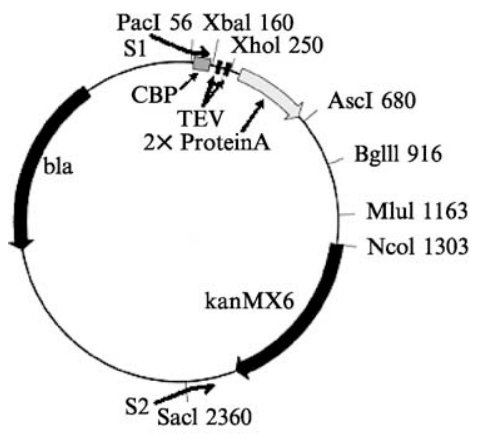

pFA6a-TAP-kanMX6

4786 bp
B
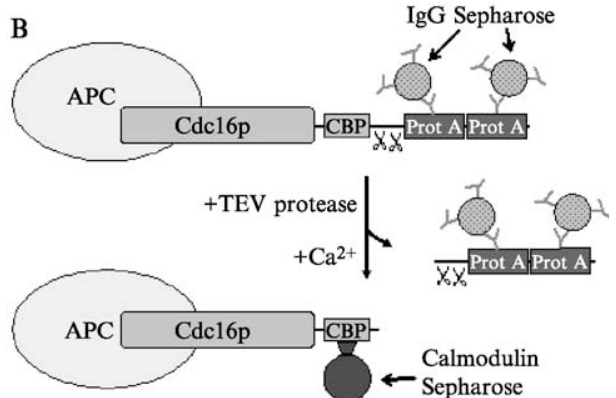

Sepharose
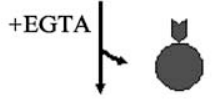

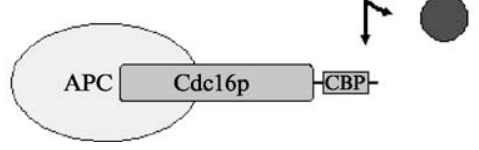

FIG. 1. Tandem affinity purification. (A) Schematic diagram of the pFA6a-TAP-kanMX6 vector. The positions of selected restriction enzyme cleavage sites are shown. The TAP tag was inserted into the $P a c \mathrm{I} / A s c \mathrm{I}$ sites of the $\mathrm{pFA6a}$ vector and includes the coding region for the calmodulin-binding peptide (CBP), two TEV protease cleavage sites, and two protein A IgGbinding domains. This vector contains an E. coli origin of replication and an ampicillin resistance gene (bla) to allow propagation in bacteria and a kanamycin/G418 resistance gene (kanMX6) for selection in yeast. Oligonucleotides used for PCR-based gene targeting (S1 and S2) are shown schematically. (B) Overview of the TAP purification strategy. Clarified yeast lysates are loaded onto an IgG Sepharose column and washed thoroughly. The C-terminal protein A IgG-binding domains (Prot A) bind to the column and are cleaved off using TEV protease. The TEV eluate is supplemented with calcium and loaded onto a calmodulin Sepharose column. The calmodulin-binding peptide (CBP) binds to the column and the column is washed. The bound protein is eluted by the addition of EGTA, which chelates the calcium, thereby disrupting the interaction between calmodulin and the calmodulin-binding peptide.

solvent exposed and not required for APC function. We tried tagging CDC16 with several different tags (Passmore, 2003) but the TAP tag (Puig et al., 2001; Rigaut et al., 1999) was the most efficient for APC purification.

The TAP tag was synthesized by recursive PCR with 14 overlapping oligonucleotides (Prodromou and Pearl, 1992) and the sequence was modified for optimal $S$. cerevisiae codon usage, avoiding repetitive DNA sequences (Passmore, 2003; Passmore et al., 2003). To increase the efficiency of TEV cleavage during purification, tandem TEV protease recognition sites were inserted within the tag. Thus, the TAP tag in pFA6a-TAPkanMX6 contains an $\mathrm{N}$-terminal calmodulin-binding peptide (originating from rabbit skeletal muscle myosin light chain kinase) (Blumenthal et al., 1985), followed by two TEV protease cleavage sites and, at its C terminus, two repeats of the Staphylococcus aureus protein A IgG-binding domain 
(Fig. 1). The following protocol (adapted from Wach et al., 1998) can be used for PCR-based gene targeting and was used to create a yeast strain expressing Cdc16-TAP.

\section{Buffers and Reagents}

10× LiAc: $1 M$ lithium acetate (Sigma L-6883) adjusted to $\mathrm{pH} 7.5$ with dilute acetic acid and filter sterilized

$10 \times$ TE: $0.1 M$ Tris, $\mathrm{pH}$ 7.5, $10 \mathrm{~m} M$ EDTA, autoclaved

LiAc/TE: $1 \times \mathrm{LiAc}, 1 \times \mathrm{TE}$, made fresh and filter sterilized

50\% PEG: 50\% (w/v) PEG 3350 (Sigma P-3640) in water (leave overnight on stirplate to allow the PEG to go into solution)

PEG/LiAc: 40\% PEG 3350 (8 ml 50\% PEG), 1× TE (1 ml 10× TE), $1 \times \operatorname{LiAc}(1 \mathrm{ml} 10 \times \mathrm{LiAc})$, prepared immediately prior to use and filter sterilized

Dimethyl sulfoxide (DMSO), Sigma D-8779

Salmon sperm DNA, Invitrogen 15632-011

YPD: For 1 liter, autoclave $20 \mathrm{~g}$ bacto-peptone and $10 \mathrm{~g}$ yeast extract in $950 \mathrm{ml}$ water. Cool to approximately $60^{\circ}$ and add sterile-filtered $2 M$ D-glucose to $0.11 M$

G418/YPD plates: For 1 liter, autoclave $20 \mathrm{~g}$ bacto-peptone, $10 \mathrm{~g}$ yeast extract, and $20 \mathrm{~g}$ bacto-agar in $950 \mathrm{ml}$ water. Cool to approximately $60^{\circ}$ and add sterile-filtered $2 \mathrm{M}$ D-glucose to $0.11 \mathrm{M}$ and sterilefiltered G418 to $300 \mu \mathrm{g} / \mathrm{ml}$ (from a $25-\mathrm{mg} / \mathrm{ml}$ stock solution; Melford G0175)

IP buffer: $50 \mathrm{~m} M$ Tris-Cl, $\mathrm{pH}$ 8.0, $150 \mathrm{~m} M \mathrm{KCl}, 10 \%$ (w/v) glycerol, $0.2 \%(\mathrm{v} / \mathrm{v})$ Triton $\mathrm{X}-100$, and protease inhibitors.

\section{Preparation of PCR Product}

Oligonucleotide primers should be $5^{\prime}$ phosphorylated and PAGE purified. S1 oligonucleotides are designed to contain $40 \mathrm{bp}$ of the $3^{\prime}$ end of gene to be tagged (up to but not including the stop codon) followed by the $24 \mathrm{bp}$ pFA6a vector sequence, such that the gene is fused, in-frame, with the tag from the vector (Fig. 1A). The S2 oligonucleotide contains $40 \mathrm{bp}$ complementary to the chromosomal region downstream of the targeted gene, followed by a $20 \mathrm{bp}$ pFA6a vector sequence. To make the Cdc16-TAP strain, we used the following oligonucleotides (with vector-specific sequences in italics):

S1-TAP-CDC16: TAATGCCGACGATGATTTTGACGCAGATA TGGAACTGGAA TCTCACGAAAAGAGAAGATGGAAG 
S2-CDC16: CTTTTACGTGTGGCTGCCTCTAAGAATTAAACT TCTTTTCCATCG ATGAATTCGAGCTCG

Perform a 200- $\mu$ PCR reaction using Expand high-fidelity polymerase (Roche Applied Science, 1732641), the S1 and S2 oligonucleotides, and the pFA6a-TAP-kanMX6 template. Use 20 cycles of PCR as follows: $95^{\circ} 30 \mathrm{~s}$, $54^{\circ} 30 \mathrm{~s}$, and $72^{\circ} 3 \mathrm{~min}$. Clean up the PCR products $(\sim 2.4 \mathrm{~kb})$ using gel purification and the QIAEX II gel purification kit (Qiagen, 20021).

\section{Transformation Protocol}

1. Inoculate a 50-ml overnight culture in YPD using one large colony of BJ2168 yeast (less than 2 weeks old). Grow for approximately $24 \mathrm{~h}$ at $30^{\circ}, 220 \mathrm{rpm}$.

2. Inoculate $300 \mathrm{ml}$ fresh YPD with overnight culture to give an $\mathrm{OD}_{600 \mathrm{~nm}}$ of 0.2 and grow at $30^{\circ}, 220 \mathrm{rpm}$ until the $\mathrm{OD}_{600 \mathrm{~nm}}$ is $0.4-0.6$.

3. Harvest cells in 50-ml Falcon tubes at $1000 \mathrm{~g}$ for $5 \mathrm{~min}$ at room temperature.

4. Combining all pellets, wash once in $30 \mathrm{ml}$ sterile water and once in $1.5 \mathrm{ml} \mathrm{LiAc/TE}$.

5. Resuspend cells in $1.5 \mathrm{ml} \mathrm{LiAc/TE}$ and make competent by incubating at $30^{\circ}$ for $30 \mathrm{~min}$ with gentle shaking (100 rpm).

6. To prepare the DNA for transformation, heat salmon sperm DNA to $100^{\circ}$ for $10 \mathrm{~min}$ and then chill quickly on ice. For each transformation, mix $100 \mu \mathrm{g}$ salmon sperm DNA with $1-4 \mu \mathrm{g}$ of PCR product in a $1.5-\mathrm{ml}$ tube. As a negative control, use TE buffer instead of PCR product.

7. Add $100 \mu \mathrm{l}$ competent yeast to the DNA and mix well.

8. Add $0.6 \mathrm{ml} \mathrm{PEG} / \mathrm{LiAc}$ solution to each tube and mix well by flicking the tube.

9. Incubate at $30^{\circ}$ for $30 \mathrm{~min}$ with shaking $(200 \mathrm{rpm})$.

10. Add $70 \mu \mathrm{l}$ DMSO, mix by gentle inversion, heat shock for $15 \mathrm{~min}$ at $42^{\circ}$, and then chill on ice for $2 \mathrm{~min}$.

11. Pellet cells at $6000 \mathrm{~g}$ for $1 \mathrm{~min}$, resuspend in $0.5 \mathrm{ml} \mathrm{YPD,} \mathrm{and}$ recover by incubation at $30^{\circ}$ and $200 \mathrm{rpm}$ for $2 \mathrm{~h}$.

12. Finally, pellet cells at $6000 \mathrm{~g}$ for $1 \mathrm{~min}$, resuspend in $0.6 \mathrm{ml} \mathrm{YPD}$, and plate onto six G418/YPD plates (100 $\mu \mathrm{l} /$ plate) using glass beads to spread the cells. Grow inverted plates for 3 days at $30^{\circ}$.

13. After 3 days, the transformed yeast grow out as large colonies on a thin lawn of background colonies. There should be no colonies on the negative control plates. Streak out several of the large colonies onto fresh G418/YPD plates to obtain single colonies. 


\section{Verification of Integration}

Integration of the purification tag at the $3^{\prime}$ end of the endogenous CDC16 gene should be verified by colony PCR as described (Wach et al., 1998). Colony PCR confirms that the integration has occurred at the correct locus and that the yeast strain is haploid for the targeted gene. Briefly, design four primers so that a PCR product from one set of primers (V1 and K2) spans the $5^{\prime}$ integration site and a PCR product from a second set of primers (K3 and V4) spans the $3^{\prime}$ integration site (V1 and V4 are gene specific; $\mathrm{K} 2$ and $\mathrm{K} 3$ are vector specific). The presence of correctly sized PCR products indicates a positive transformant. PCR reactions are performed in tubes containing a small quantity of yeast microwaved on high power for $1 \mathrm{~min}$ (Wach et al., 1998). For the CDC16-TAP strain, the following oligonucleotides were used:

V1-CDC16: GCACAAATCAT TGTACCTAAAGCC

V4-CDC16: GGAACCTTGAACTTGAACAGCG

K2-kanMX6: CGGATGTGATGTGAGAACTGTATCCTAGC

K3-kanMX6: GCTAGGATACAGT TCTCACATCACATCCG

The PCR products should be $1.6 \mathrm{~kb}$ with V1-CDC16 and K2-kanMX6; 1.4 $\mathrm{kb}$ with K3-kanMX6 and V4-CDC16; and $3.1 \mathrm{~kb}$ with V1-CDC16 and V4CDC16 (0.7 kb for a wild-type strain).

A small proportion of clones that have integrated tags as determined by colony PCR do not express functional tags, perhaps due to frameshifts or other mutations. Therefore, small-scale immunoprecipitations should also be performed for several clones to test for the presence of functional tags. Inoculate $200 \mathrm{ml}$ YPD with $5 \mathrm{ml}$ of a saturated overnight culture and grow at $30^{\circ}$ with shaking $(200 \mathrm{rpm})$ until the $\mathrm{OD}_{600 \mathrm{~nm}}$ is $0.6-1.0$. (Use untagged BJ2168 yeast for a negative control.) Harvest cells by centrifugation at $3000 \mathrm{~g}$ for $12 \mathrm{~min}$ at $4^{\circ}$. Rinse pellets once with cold water, flash freeze in a dry ice/ethanol bath, and store at $-80^{\circ}$. For immunoprecipitations, add an equal volume of acid-washed glass beads (425-600 $\mu \mathrm{m}$; Sigma) to frozen cell pellets and IP buffer to cover the glass beads $(\sim 0.4 \mathrm{ml})$. Lyse yeast by vortexing on maximum speed at $4^{\circ}$ for $30 \mathrm{~s}$, followed by a 30 -s incubation on ice, for a total of $8 \mathrm{~min}$ of vortexing. Transfer the lysate, without glass beads, into $1.5-\mathrm{ml}$ tubes and centrifuge at $20,000 \mathrm{~g}$ for $20 \mathrm{~min}$ at $4^{\circ}$. Transfer the supernatant to a new tube and estimate the protein concentration using the Bio-Rad protein assay.

Equilibrate $20 \mu \mathrm{l}$ of IgG Sepharose (Amersham Biosciences 17-0969-01) in IP buffer. Add equal amounts of protein extract to the resin and incubate at $4^{\circ}$ on a pinwheel rotor for $1 \mathrm{~h}$. Wash IgG Sepharose three times with IP buffer. To elute protein, add $40 \mu \mathrm{l} 2 \times$ SDS-PAGE sample buffer to each sample and vortex. Boil samples for $10 \mathrm{~min}$, vortex, and load 
directly onto an $8 \%$ SDS-PAGE large gel. Western blot with anti-Protein A antibody (SPA-27, Sigma P-2921; 1:2400 dilution). Cdc16-TAP should be visible as a $118-\mathrm{kDa}$ band ( $99 \mathrm{kDa}$ after TEV cleavage).

\section{Purification of Yeast $\mathrm{APC}^{\mathrm{CDC} 16-\mathrm{TAP}}$}

The TAP purification protocol (Passmore et al., 2003) was modified from Rigaut et al. (1999) and is outlined in Fig. 1B. We routinely perform the entire purification in 1 day over $\sim 12 \mathrm{~h}$. However, the purification can be stopped before TEV cleavage and stored overnight at $4^{\circ}$.

\section{Yeast Cultures}

To prepare yeast pellets, use a saturated overnight culture, grown from one or two fresh CDC16-TAP yeast colonies, to inoculate 10-20 liters of YPD (0.5-2.0 $\mathrm{ml}$ overnight culture per liter YPD in a 2-liter flask). Grow yeast cultures overnight with shaking $(200 \mathrm{rpm})$ at $30^{\circ}$ to an $\mathrm{OD}_{600 \mathrm{~nm}}$ of approximately 1.0. The cells must be harvested before they reach stationary phase, as the major yeast proteases become more active, the cell wall becomes thicker, and protein synthesis decreases at stationary phase (Jones, 2002; Werner-Washburne et al., 1993). Harvest the yeast at $3000 \mathrm{~g}$ for $12 \mathrm{~min}$ at $4^{\circ}$, rinse once in cold water (to remove extracellular proteases), flash freeze in a dry ice/ethanol bath or liquid nitrogen, and store at $-80^{\circ}$.

\section{Buffers and Reagents}

Buffers used for large-scale purifications are in italics and are listed in Table I. All purification steps should be performed at $4^{\circ}$ unless otherwise indicated. It is important to prechill buffers to $4^{\circ}$ before adjusting the $\mathrm{pH}$ due to the temperature dependence of Tris buffers. To avoid problems with $\mathrm{pH}$ fluctuations, HEPES buffer can be used instead of Tris.

To prepare IgG Sepharose FF (Amersham Biosciences 17-0969-01), pack the resin into a Vantage $\mathrm{L}$ column (Amicon) using $0.125 \mathrm{ml}$ resin for every $10 \mathrm{~g}$ of yeast pellet. An empty PD10 column (Amersham Biosciences), or similar gravity flow column, may also be used. However, we have observed that lower yields are obtained using gravity flow columns. Wash the column with five bed volumes of TST (Table I). To remove unbound $\mathrm{IgG}$, wash with three bed volumes each of $0.5 \mathrm{M} \mathrm{HAc}$, TST, and 0.5 M HAc. Wash the column thoroughly with TST until the $\mathrm{pH}$ returns to 7.6 (monitor the $\mathrm{pH}$ using $\mathrm{pH}$ strips). Chill it to $4^{\circ}$ and equilibrate with $\operatorname{Ig} G$ buffer 1 just before use. To prepare calmodulin Sepharose 4B (Amersham 
TABLE I

BUFFERS FOR APC PURIFICATION

\begin{tabular}{|c|c|}
\hline Buffer name & Composition \\
\hline TST & $50 \mathrm{~m} M$ Tris- $\mathrm{Cl}, \mathrm{pH}$ 7.6, $150 \mathrm{~m} M \mathrm{NaCl}, 0.05 \%(\mathrm{v} / \mathrm{v})$ Tween 20 \\
\hline $0.5 M \mathrm{HAc}$ & $0.5 \mathrm{M}$ acetic acid, adjusted to $\mathrm{pH} 3.4$ with $\mathrm{NH}_{4} \mathrm{CH}_{3} \mathrm{COOH}$ \\
\hline Lysis buffer & $50 \mathrm{~m} M$ Tris-Cl, pH 8.0, $150 \mathrm{~m} M \mathrm{KCl}, 10 \%$ (w/v) glycerol \\
\hline DNase I & $1 \mathrm{mg} / \mathrm{ml} \mathrm{DNase}$ I (Roche 104159) in water \\
\hline Igepal CA-630 & $10 \%(v / v)$ Igepal CA-630 (Sigma I-3021) in water \\
\hline IgG buffer 1 & $\begin{array}{l}50 \mathrm{~m} M \text { Tris-Cl, } \mathrm{pH} 8.0,150 \mathrm{~m} M \mathrm{KCl}, 10 \% \text { (w/v) glycerol, } \\
0.5 \mathrm{~m} M \text { EDTA, } 2 \mathrm{~m} M \text { EGTA, } 0.1 \%(\mathrm{v} / \mathrm{v}) \text { Igepal CA- } 630\end{array}$ \\
\hline IgG buffer 2 & $\begin{array}{c}50 \mathrm{~m} M \text { Tris-Cl, pH } 8.0,150 \mathrm{~m} M \mathrm{KCl}, 10 \% \text { (w/v) glycerol, } \\
0.5 \mathrm{~m} M \text { EDTA, } 1 \mathrm{~m} M \text { DTT, } 0.1 \%(\mathrm{v} / \mathrm{v}) \text { Igepal CA-630 }\end{array}$ \\
\hline CaM wash buffer & $\begin{array}{l}10 \mathrm{~m} M \text { Tris-Cl, } \mathrm{pH} 8.0,150 \mathrm{~m} M \mathrm{NaCl}, 10 \%(\mathrm{w} / \mathrm{v}) \text { glycerol, } \\
3 \mathrm{~m} M \text { DTT, } 1 \mathrm{~m} M \text { Mg-acetate, } 2 \mathrm{~m} M \mathrm{CaCl}_{2}, 0.1 \%(\mathrm{v} / \mathrm{v}) \\
\text { Igepal CA- } 630\end{array}$ \\
\hline CaM elution buffer & $\begin{array}{l}10 \mathrm{~m} M \text { Tris-Cl, } \mathrm{pH} 8.0,150 \mathrm{~m} M \mathrm{NaCl}, 10 \%(\mathrm{w} / \mathrm{v}) \text { glycerol, } \\
3 \mathrm{~m} M \text { DTT, } 1 \mathrm{~m} M \text { Mg-acetate, } 2 \mathrm{~m} M \text { EGTA, } 0.1 \%(\mathrm{v} / \mathrm{v}) \\
\text { Igepal CA- } 630\end{array}$ \\
\hline Protease inhibitors & $\begin{array}{l}\text { Complete EDTA-free protease inhibitor cocktail tablets } \\
\text { (Roche Applied Science 1873580). Add one tablet for } \\
\text { every } 100 \mathrm{ml} \text { buffer }\end{array}$ \\
\hline Phosphatase inhibitors & $\begin{array}{l}50 \mathrm{~m} M \mathrm{NaF}, 25 \mathrm{~m} M \beta \text {-glycerophosphate, } 1 \mathrm{~m} M \\
\text { Na-orthovanadate }\end{array}$ \\
\hline
\end{tabular}

Biosciences 17-0529-01), pack $0.1 \mathrm{ml}$ resin per $10 \mathrm{~g}$ yeast pellet into a BioRad polyprep column or empty PD10 column. Wash the column with 10 bed volumes of water and then with 20 bed volumes of CaM wash buffer and chill to $4^{\circ}$.

\section{Preparation of Yeast Extracts}

1. Thaw cell pellets from 10 to 20 liters yeast culture at room temperature and resuspend in an equal volume of lysis buffer with protease inhibitors and phosphatase inhibitors. Add 1/1000 volume DNase I.

2. Lyse cells by passing through an Emusiflex C5 homogenizer (Avestin, Canada) on ice, four times at 20,000 psi. The Emulsiflex C5 homogenizer uses a high-pressure pump to push a continuous flow of cell paste through an adjustable homogenizing valve. Cells are subjected to a shear force due to the rapid change in pressure at the homogenizing valve as well as a physical force due to impact with the homogenizing valve, resulting in cell lysis. We have also successfully used a French press to lyse the cells. 
3. Clear lysate by centrifuging in a JA20 Beckman rotor at $19,000 \mathrm{rpm}$ $(45,000 \mathrm{~g})$ for $30 \mathrm{~min}$ at $4^{\circ}$. (The lysate remains quite turbid after centrifugation.)

4. Add EDTA to a final concentration of $0.5 \mathrm{~m} M$ (from $0.5 M$ EDTA stock) and Igepal CA-630 (a nonionic detergent) to a final concentration of $0.1 \%(\mathrm{v} / \mathrm{v})$.

\section{Purification on IgG Sepharose}

1. Load the cleared lysate onto the IgG Sepharose Vantage column at $0.5-1.0 \mathrm{ml} / \mathrm{min}$ using a P1 pump (or slowly pass the lysate over the column, trying not to disturb the bed of resin, if using a gravity flow column).

2. Wash the IgG column with 60 bed volumes of $\operatorname{IgG}$ buffer 1 with protease inhibitors and phosphatase inhibitors, followed by 30 bed volumes of IgG buffer 2 with phosphatase inhibitors. The EGTA in IgG buffer 1 chelates calcium to release any calmodulin that may be bound to the calmodulin-binding peptide. We have observed that if EGTA is omitted from IgG buffer 1 , only $\sim 60 \%$ of the APC binds to the calmodulin column. This suggests that endogenous yeast calmodulin binds to the calmodulin-binding peptide of the tagged APC subunit during purification and blocks binding to calmodulin resin. (The purification may be stopped here and stored overnight if necessary.)

3. Carefully remove resin from the IgG column and transfer it into round-bottomed 2-ml tubes. For every $100 \mu \mathrm{l}$ of IgG Sepharose, add $100 \mu \mathrm{l}$ IgG buffer 2 and approximately 10 units (or $15 \mu \mathrm{g}$ ) TEV protease (Invitrogen, 10127-017). Shake the cleavage reactions at $16^{\circ}, 100 \mathrm{rpm}$ for $2 \mathrm{~h}$.

4. After cleavage, the APC should be present in the supernatant. Spin down the resin $\left(1000 g, 1 \mathrm{~min}, 4^{\circ}\right)$. Remove the supernatant and wash the resin twice with a small volume of $\operatorname{Ig} G$ buffer 2 (approx. 0.3 bed volumes each wash). Pool the TEV supernatant and washes. In our hands, approximately $95 \%$ of Cdc16-TAP is cleaved and eluted with TEV protease, as shown by immunoblotting for the protein A tag.

5. Spin the supernatant at $10,000 \mathrm{~g}$ for $1 \mathrm{~min}$ to ensure all $\mathrm{IgG}$ beads are removed.

\section{Purification on Calmodulin Resin}

1. To the supernatant from the TEV cleavage reaction, add $1 M \mathrm{CaCl}_{2}$ to a final concentration of $5 \mathrm{~m} M$. Save $35 \mu \mathrm{l}$ for SDS-PAGE analysis.

2. Incubate the TEV supernatant with calmodulin Sepharose in a sealed column on rollers for $1 \mathrm{~h}$ at $4^{\circ}$. The calmodulin-binding 
peptide of the TAP tag will bind to calmodulin in the presence of calcium.

3. After binding, allow the column to drain by gravity (save $35 \mu \mathrm{l}$ of this flow through for SDS-PAGE analysis). Wash with 70 bed volumes CaM wash buffer by carefully pipetting several milliliters of buffer onto the resin at a time, trying to maintain an even bed of resin.

4. Elute protein from the calmodulin Sepharose in CaM elution buffer in at least 15 fractions of one bed volume each. Be careful not to disturb the bed of resin when pipetting elution buffer. The APC usually elutes in fractions $2-6$.

\section{Analysis and Concentration}

5. Analyze samples by SDS-PAGE on an $18 \times 16-\mathrm{cm} 8 \%$ SDSpolyacrylamide gel and silver stain using the method of Ansorge (1985). Generally, $35 \mu \mathrm{l}$ of the TEV eluate or $100 \mu \mathrm{l}$ of each calmodulin elution fraction should be loaded onto the gel. We can resolve all of the APC subunits (except Apc4 and Apc5, which run at the same position, Fig. 2) using a modified gel composition of

Resolving gel: $0.75 M$ Tris, $\mathrm{pH}$ 9.2, $8 \% \quad 37.5: 1$ acrylamide:bisacrylamide, $0.1 \%(\mathrm{w} / \mathrm{v})$ SDS

Stacking gel: $0.25 M$ Tris, $\mathrm{pH}$ 6.8, 5.1\% 37.5:1 acrylamide:bisacrylamide, $0.1 \%(\mathrm{w} / \mathrm{v})$ SDS

Running buffer: $25 \mathrm{~m} M$ Tris, $192 \mathrm{~m} M$ glycine, $\mathrm{pH}$ 8.3, 0.1\% SDS

6. Pool the calmodulin elution fractions containing the APC (usually fractions 2-6 contain most of the APC).

7. Concentrate the pooled fractions using YM-50 Centricons or YM-50 Microcons (Millipore). Estimate the protein concentration using the Bio-Rad protein assay and a bovine serum albumin calibration standard made up in CaM elution buffer. For in vitro assays, a concentration of $0.05-0.1 \mathrm{mg} / \mathrm{ml}$ is sufficient.

8. Aliquot the concentrated protein, flash freeze in dry ice/ethanol or liquid nitrogen, and store at $-80^{\circ}$. Purified APC loses activity after multiple freeze-thaws.

\section{Comments}

A silver-stained gel of a typical APC purification is shown in Fig. 2. After the first two steps of the TAP purification (purification on an IgG Sepharose column and elution with TEV protease), a series of bands 


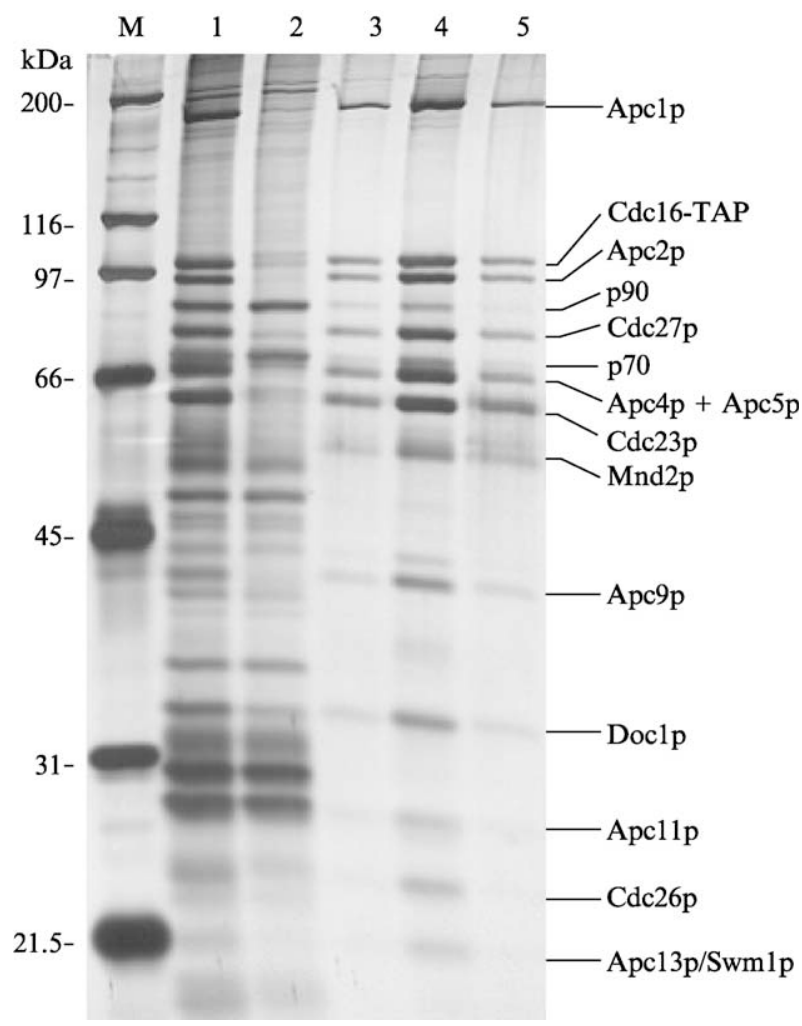

FIG. 2. TAP purification of endogenous APC from S. cerevisiae. Analysis of APC purification from $C D C 16-T A P$ yeast by silver-stained SDS-PAGE. Cdc16-TAP binds to IgG Sepharose and is eluted by cleavage with TEV protease (eluate, lane 1). The eluate is bound to calmodulin Sepharose (flow through, lane 2), washed, and eluted with EGTA (elution fractions, lanes 3-5). Proteins identified by MALDI-TOF mass spectrometry are labeled. p90 is a Cdc16p degradation product, and p70 is the Hsp70 family heat shock protein Ssa2. The diffuse band at 55-60 kDa contains keratins, which originate in contaminated SDS stock solutions. M, molecular weight markers. Reproduced from Passmore et al. (2003) with permission.

corresponding to the correct molecular weights for APC subunits is visible (Fig. 2, lane 1). After subsequent purification on calmodulin resin, the APC is $\sim 95 \%$ pure (Fig. 2, lanes 3-5) with a yield of $\sim 10-50 \mu \mathrm{g}$ APC from 10 liters of yeast culture. In contrast, a negative control purification from untagged BJ2168 yeast yields no major purified proteins (not shown). We have confirmed the identities of all of the 13 APC subunits using MALDITOF mass spectrometry (Passmore et al., 2003). We also identified two 
contaminating proteins: $\mathrm{p} 90$ is a $90-\mathrm{kDa}$ degradation product of $\mathrm{Cdc} 16$ whereas p70 is the Hsp70 family heat shock protein Ssa2. Hsp70 binds to extended hydrophobic polypeptide segments (Bukau and Horwich, 1998), but its presence does not necessarily indicate unfolding or disassembly of the APC because it is often a contaminant in protein purifications. Ssa2 is a highly expressed protein (Garrels et al., 1997) and it had a high frequency of occurrence in genome-wide mass spectrometric studies in yeast, being present in up to $54 \%$ of all protein purifications, as well as in mock purifications from untagged strains (Gavin et al., 2002; Ho et al., 2002). The relative intensities of p90 and p70 on SDS-PAGE decrease after concentration of the APC, probably because they are not integral components of the APC and they pass through the concentrator membrane.

We have examined the stability of the APC in response to $\mathrm{pH}$ change (Passmore, 2003). These studies showed that APC is highly sensitive to $\mathrm{pH}$ less than 7.5 and that low $\mathrm{pH}$ may cause the APC to precipitate or dissociate. The APC is stable at higher $\mathrm{pH}$ and it should be purified in a buffer with a $\mathrm{pH}$ of 8.0. Because the $\mathrm{pH}$ of Tris buffers is temperature dependent, one must ensure that all buffers are kept at $4^{\circ}$ and that APC is stored on ice. (As mentioned earlier, we have also used HEPES buffer to avoid this problem.)

The TAP tag was designed specifically to allow for the efficient recovery of proteins present in low quantities (Rigaut et al., 1999). Its success is probably dependent on several factors. First, both the protein A-IgG and calmodulin-binding peptide (CBP)-calmodulin interactions are high affinity. For the CBP-calmodulin interaction, the $K_{\mathrm{d}}$ is less than $10 \mathrm{n} M$ (Blumenthal et al., 1985). The affinity of the protein A-IgG interaction varies with the type of $\mathrm{IgG}$ and the $\mathrm{pH}$ but it should bind tightly under the conditions used here (human IgG and pH 8.0; Harlow and Lane, 1999). Second, these protein-protein interactions are very specific, unlike those found in many other affinity/epitope tags. Finally, the elution methods (TEV cleavage from IgG Sepharose and EGTA elution from calmodulin Sepharose) are specific and gentle, preventing dissociation of the protein complex.

\section{Assay of APC Using Native Substrates}

As an E3 ubiquitin ligase, the in vivo role of the APC is to catalyze the conjugation of polyubiquitin chains onto specific substrate proteins. This activity is regulated both spatially and temporally. We have developed an in vitro ubiquitination assay to study APC activity against endogenous yeast targets and therefore in a physiologically relevant context (Passmore, 
A
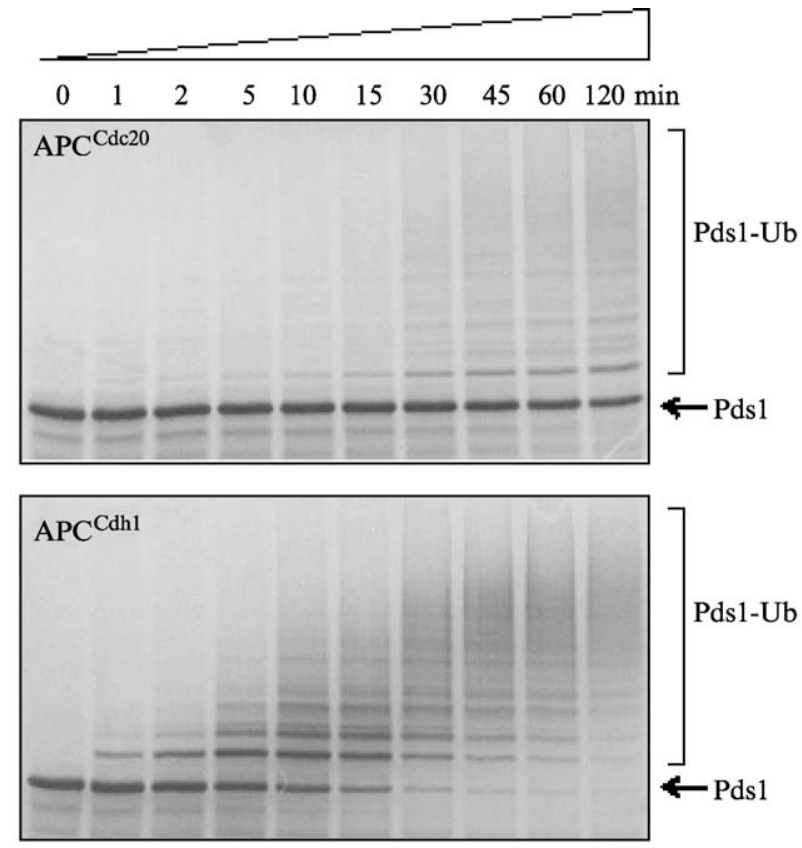

B

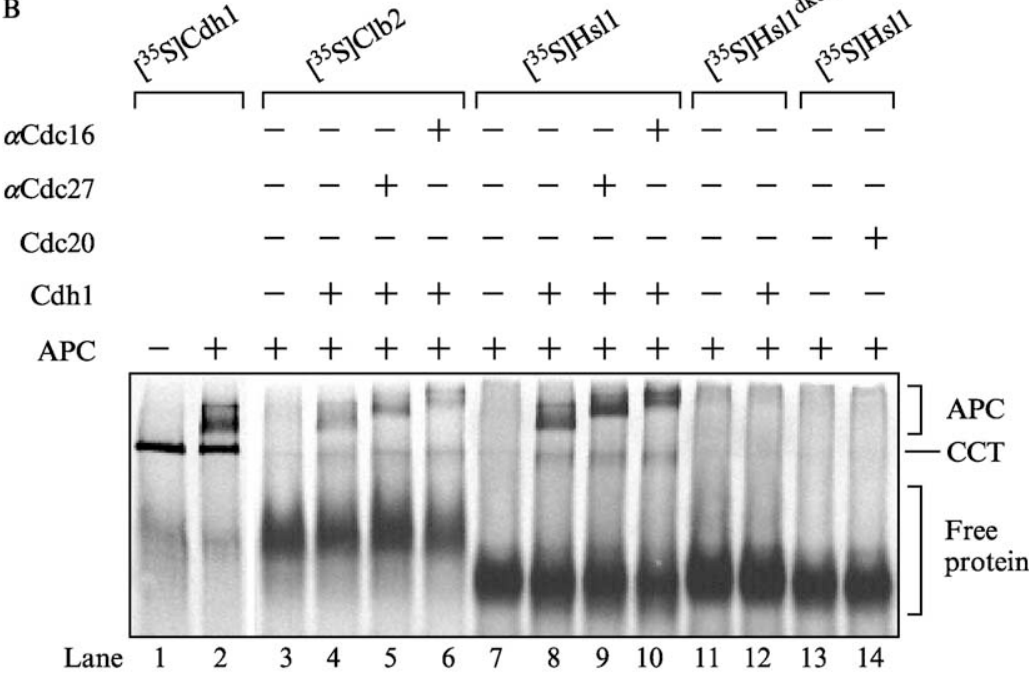


2003; Passmore et al., 2003). Purified APC is incubated with yeast E2 (Ubc4p), ubiquitin, ATP, and ${ }^{35} \mathrm{~S}$-labeled substrate, and the entire reaction mixture is analyzed by SDS-PAGE followed by autoradiography. Using this assay, purified yeast APC is active as an E3 ubiquitin ligase toward specific yeast substrates, including Pds1, Clb2, and Hsl1, but it is not active toward, nonphysiological substrates such as Cln1 (Fig. 3A) (Passmore et al., 2003). The activity of the APC is dependent on the presence of either the Cdc20 or the Cdh1 coactivator. It catalyzes the formation of polyubiquitin chains onto substrate, resulting in high molecular weight polyubiquitinated products. Thus, the in vitro assay reflects the in vivo function of the APC.

\section{Buffers and Reagents}

Plasmids: All plasmids are constructed using $S$. cerevisiae open reading frames (ORFs). APC substrates (Pds1, Clb2, and Hsl1) and coactivators (Cdc20 and Cdh1) are cloned into vectors containing a T7 promoter (either pET or pRSET) so they can be produced by in vitro transcription/translation (IVT). All plasmids for IVT should be highly purified, e.g., using the HiSpeed plasmid midi kit (Qiagen 12643).

$20 \times$ ubiquitination buffer: $800 \mathrm{~m} M$ Tris, $\mathrm{pH} 7.5,200 \mathrm{~m} M \mathrm{MgCl}_{2}, 12$ $\mathrm{m} M$ dithiothreitol (DTT). Aliquot and store at $-20^{\circ}$.

0.1 $M$ ATP (Amersham Biosciences 27-2056-01): Aliquot and store at $-20^{\circ}$. Avoid multiple freeze-thaws.

$5 \mathrm{mg} / \mathrm{ml}$ ubiquitin: Dissolve ubiquitin (Affiniti, UW8795) to $5 \mathrm{mg} / \mathrm{ml}$ in $10 \mathrm{~m} M$ Tris, $\mathrm{pH}$ 7.0. Aliquot and store at $-20^{\circ}$.

E2: His 6 -Ubc4p (E2) can be overexpressed and purified from Escherichia coli using standard procedures. Dilute purified Ubc4 to $500 \mathrm{ng} / \mu \mathrm{l}$ in $10 \mathrm{~m} M$ Tris, $\mathrm{pH} 7.5,150 \mathrm{mM} \mathrm{NaCl}$, and $2 \mathrm{~m} M$ DTT. Aliquot and store at $-80^{\circ}$.

FIG. 3. In vitro APC assays. (A) Time courses of the activities of APC with Cdc20 $\left(\mathrm{APC}^{\mathrm{Cdc} 20}\right)$ and $\mathrm{APC}$ with $\mathrm{Cdh} 1\left(\mathrm{APC}^{\mathrm{Cdh} 1}\right)$ toward the substrate Pds1. APC was incubated with E2 (Ubc4), ubiquitin, ATP, ${ }^{35}$ S-labeled substrate, and one of the coactivators, Cdc20 or Cdh1. Samples were taken at the indicated time points and added to SDS-PAGE loading buffer. The addition of polyubiquitin chains onto ${ }^{35} \mathrm{~S}$-labeled Pds1 results in the appearance of high molecular weight smears correlating with the disappearance of unmodified Pds1 from the bottom of the gel. (B) Analysis of APC-coactivator and APC-substrate interactions. In the first two lanes ${ }^{35} \mathrm{~S}-\mathrm{Cdh} 1$ was incubated with and without APC. In the remaining lanes, ${ }^{35}$ S-labeled Clb2, 6His-Hsl1 ${ }^{667-872}$, or 6 His-Hsl1 containing D- and KEN-box mutations (6His-Hsl1 $\left.{ }^{667-872} \mathrm{dkbm}\right)$ were mixed with APC in the presence or absence of Cdh1 or Cdc20. All samples were run on a native gel and analyzed by autoradiography. Antibodies to Cdc27 or Cdc16, which retard the migration of the APC, were added to some samples. Reproduced from Passmore et al. (2003) with permission. 
$1 \mu \mathrm{g} / \mu \mathrm{l}$ ubiquitin aldehyde: Dissolve ubiquitin aldehyde (Affiniti, UW8450) to $1 \mu \mathrm{g} / \mu \mathrm{l}$ in $10 \mathrm{~m} M$ Tris, $\mathrm{pH}$ 7.0. Aliquot and store at $-20^{\circ}$. $200 \mu M$ LLnL: Dissolve LLnL ( $N$-acetyl-Leu-Leu-Norleu-al; Sigma A6185) to $20 \mathrm{~m} M$ in DMSO and then dilute to $200 \mu M$ with water. Aliquot and store at $-20^{\circ}$.

APC buffer: $10 \mathrm{~m} M$ Tris, $\mathrm{pH} 8.0,150 \mathrm{~m} M \mathrm{NaCl}, 10 \%$ (w/v) glycerol, $1 \mathrm{~m} M \mathrm{Mg}$-acetate, $0.01 \%$ (v/v) Igepal CA-630, $2 \mathrm{~m} M$ EGTA, and $3 \mathrm{~m} M$ DTT. Aliquot and store at $-20^{\circ}$.

$4 \times$ SDS-PAGE loading buffer: $0.2 M$ Tris-Cl, $\mathrm{pH} 6.8,8 \%$ (w/v) SDS, $40 \%(\mathrm{v} / \mathrm{v})$ glycerol, $20 \%(\mathrm{v} / \mathrm{v}) 2$-mercaptoethanol, and bromphenol blue to color.

\section{In Vitro Transcription/Translation}

Coactivators and substrates are obtained using a rabbit reticulocytecoupled in vitro transcription/translation (IVT) system, as these proteins are difficult to purify from overexpression systems. The incorporation of $\left[{ }^{35} \mathrm{~S}\right]$ methionine into the IVT system also provides a convenient and sensitive mechanism to label substrates for direct visualization on autoradiograms. A problem with using IVT-produced proteins is that other proteins from the IVT mixture might affect the assay. In these ubiquitylation assays, proteins independent of Cdc20 or Cdh1 are not activating the APC because the addition of reticulocyte lysate alone does not stimulate APC activity (Passmore et al., 2003).

Prepare substrates and coactivators by IVT using the TNT T7 Quick coupled in vitro transcription/translation kit (Promega L1170). The TNT T7 Quick IVT system contains T7 RNA polymerase, nucleotides, salts, and ribonuclease inhibitor for in vitro transcription from a $\mathrm{T} 7$ promoter, as well as a rabbit reticulocyte lysate solution and amino acids to allow in vitro translation. Therefore, when a plasmid containing a gene under the control of a T7 promoter is incubated in the TNT solution, the gene product is expressed and may undergo posttranslational processing (e.g., chaperonemediated folding). The IVT reactions should be performed fresh for each assay, as freeze/thaw cycles inactivate $\mathrm{Cdc} 20$ and $\mathrm{Cdh} 1$. For ubiquitination assays, synthesize substrates using $\left[{ }^{35} \mathrm{~S}\right]$ methionine and coactivators using unlabeled methionine. For $\left[{ }^{35}\right.$ S $]$ methionine IVT reactions, use $40 \mu \mathrm{l}$ TNT T7 Quick Master Mix, $1 \mu \mathrm{g}$ plasmid DNA, $4 \mu \mathrm{l}\left[{ }^{35}\right.$ S]methionine (Redivue L- $\left[{ }^{35}\right.$ S $]$ methionine, Amersham AG1594), and water to $50 \mu \mathrm{l}$. For IVT reactions with unlabeled methionine, use $1 \mu \mathrm{l} 1 \mathrm{~m} M$ methionine instead of $\left[{ }^{35} \mathrm{~S}\right]$ methionine. Incubate the reactions at $30^{\circ}$ for $90 \mathrm{~min} .\left[{ }^{35} \mathrm{~S}\right]$ Methionine-labeled reactions can be checked by running $3 \mu \mathrm{l}$ on SDS-PAGE (see later). 


\section{Ubiquitination Assays}

Ubiquitination assays are performed in $10-\mu \mathrm{l}$ reaction volumes containing $0.50 \mu \mathrm{l} 20 \times$ ubiquitination buffer

$0.27 \mu \mathrm{l} 0.1 \mathrm{M}$ ATP

$1.33 \mu \mathrm{l} 5 \mathrm{mg} / \mathrm{ml}$ ubiquitin

$2.00 \mu \mathrm{l}$ purified E2 (yeast Ubc4, $500 \mathrm{ng} / \mu \mathrm{l}$ )

$0.20 \mu \mathrm{l} 1 \mathrm{mg} / \mathrm{ml}$ ubiquitin aldehyde

$0.10 \mu \mathrm{l} 200 \mu M \mathrm{LLnL}$

$1.00 \mu \mathrm{l}^{35} \mathrm{~S}$-labeled substrate (produced in IVT)

$0.67 \mu \mathrm{l}$ purified APC $(\sim 50 \mathrm{ng} / \mu \mathrm{l})$

$2.00 \mu \mathrm{l}$ unlabeled $\mathrm{Cdc} 20$ or Cdh1 (produced in IVT)

$1.93 \mu \mathrm{l} \mathrm{H}_{2} \mathrm{O}$

Prepare a reaction mixture on ice containing the ubiquitination buffer, ATP, ubiquitin, E2, ubiquitin aldehyde, LLnL, and water and then add substrate, APC, and coactivator as required. Incubate the reaction at room temperature for $45 \mathrm{~min}$ and stop it by adding $4 \mu \mathrm{l}$ of $4 \times$ SDS-PAGE loading buffer. For negative controls, substitute APC with APC buffer, or coactivator with mock IVT reaction (i.e., IVT without plasmid). To control for substrate specificity, D- and/or KEN-box substrate mutants or nonphysiological substrates may be used.

Ubiquitin aldehyde is a specific inhibitor of ubiquitin C-terminal hydrolases (Hershko and Rose, 1987; Melandri et al., 1996; Pickart and Rose, 1986) and is included to prevent the hydrolysis of polyubiquitin chains. The proteasome inhibitor LLnL (Orlowski et al., 1993; Vinitsky et al., 1992) is included to prevent degradation of the polyubiquitinated proteins. The addition of exogenous E1 does not enhance the ubiquitination reaction, as E1 is abundant in reticulocyte lysate (Ciechanover et al., 1982; Haas and Bright, 1988). The optimal amounts of Ubc4 and APC should be determined by titration, as different preparations will have different activities.

\section{SDS-PAGE and Autoradiography}

For SDS-PAGE, standard gel compositions should be used (Sambrook and Russell, 2001) with the Bio-Rad Mini-PROTEAN 3 system (or similar). For visualizing ubiquitinated products, $8 \%$ minigels $(8 \times 7.3-\mathrm{cm}$ gel plates) with 15 -well combs provide good resolution. Run the entire reaction mixture $(14 \mu \mathrm{l})$ on the gel at $140 \mathrm{~V}$ until the dye front reaches the bottom. Stain the gel with Coomassie blue (50\% methanol, $10 \%$ acetic acid), destain ( $20 \%$ methanol, $10 \%$ acetic acid), dry on Whatman paper at $80^{\circ}$ for $1 \mathrm{~h}$, and expose to BioMax MR-1 film (Kodak). 
In the presence of E1, E2, ubiquitin, ATP, and ${ }^{35}$ S-labeled substrate, active APC conjugates ubiquitin proteins onto the substrate to form a polyubiquitin chain. As successive ubiquitins are added onto the substrate, its molecular mass increases by $8.6-\mathrm{kDa}$ increments (the molecular mass of ubiquitin). On the autoradiogram, a ladder of ${ }^{35} \mathrm{~S}$-labeled substrate appears, increasing in average molecular weight as the reaction proceeds (Fig. 3A). Whereas other assays have only detected the conjugation of monoubiquitin onto one to three substrate lysines, this assay shows polyubiquitin chain formation. The APC with Cdh1 $\left(\mathrm{APC}^{\mathrm{Cdh} 1}\right)$ is more active than the APC with $\mathrm{Cdc} 20\left(\mathrm{APC}^{\mathrm{Cdc} 20}\right)$ perhaps due to more efficient processing of Cdh1 relative to Cdc20 in the reticulocyte lysate (Passmore et al., 2003).

Visualization of APC-Coactivator and APC-Substrate Complexes by Native Gel Electrophoresis

Because the core APC is active in ubiquitination reactions, it must interact with coactivators, E2, and substrates. To examine these interactions further, we have used an APC-binding assay (Passmore et al., 2003). Traditional binding assays on columns could not be used, as IVT-produced Cdc20 and Cdh1 bind nonspecifically to affinity resins such as calmodulin Sepharose and Ni-NTA agarose. Native gels separate proteins based on their size, shape, and charge and therefore can be used to investigate protein-protein interactions that alter one or more of these parameters. A native gel system had been used previously to examine the interactions of the chaperonin containing TCP1 (CCT) with its substrates, one of which is Cdh1 (E. A. McCormack and K. R. Willison, unpublished results) (Liou and Willison, 1997; Valpuesta et al., 2002). A modified version of this native gel assay using purified APC and proteins produced using IVT can be used to examine APC interactions (Passmore et al., 2003).

\section{APC-Coactivator Interactions}

To examine APC-coactivator interactions, ${ }^{35} \mathrm{~S}$-labeled $\mathrm{Cdh} 1$ produced using IVT is mixed with purified APC. Interactions with APC can be monitored by changes in the mobility of the labeled coactivator. ${ }^{35} \mathrm{~S}$ labeled Cdh1 migrates as two species on a native gel (Fig. 3B, lane 1). A diffuse, faster migrating band probably represents free Cdh1, whereas a slower, more discrete band corresponds with the migration of CCT. This CCT comes from the rabbit reticulocyte lysate and is required for proper Cdh1 processing (Camasses et al., 2003). (CCT is a eukaryotic chaperonin that binds to specific substrates and assists in their folding.) Upon addition 
of APC, two additional bands appear (Fig. 3B, lane2). These bands migrate very slowly in native gels and represent APC-coactivator complexes, as they undergo a band shift upon the addition of antibodies directed against APC subunits (Passmore et al., 2003). In addition, they correspond with the migration position of purified APC (Passmore et al., 2003).

Binding reactions are performed in $14 \mu \mathrm{l}$ with the following compositions:

$2 \mu \mathrm{l}$ purified APC ( $50 \mathrm{ng})$ or CaM elution buffer (Table I) for negative control

$2 \mu \mathrm{l}^{35} \mathrm{~S}$-labeled Cdh1 (produced in IVT as described earlier)

$0.7 \mu \mathrm{l} 100 \mathrm{~m} M \mathrm{CaCl}_{2}$

$\mathrm{CaCl}_{2}$ is required for proper migration on the native gels (E. A. McCormack, unpublished results). Adjust the volume to $14 \mu \mathrm{l}$ with binding buffer (10 $\mathrm{m} M$ Tris-Cl, $\mathrm{pH} 8.0,150 \mathrm{~m} M \mathrm{NaCl}, 3 \mathrm{~m} M$ DTT, $1 \mathrm{~m} M$ Mg-acetate, $2 \mathrm{~m} M$ EGTA). Incubate samples at room temperature for $15 \mathrm{~min}$, add 1.5 $\mu \mathrm{l}$ native gel sample buffer (see later), and load the entire reaction onto a $5.25 \%$ native gel.

We have observed that lower amounts of Cdc20 bind to the APC than Cdh1 in the native gel assay (Passmore et al., 2003). Instead, most $\mathrm{Cdc} 20$ remains bound to CCT, suggesting that yeast Cdc20 is processed poorly by rabbit CCT. This Cdc20 interacts poorly with the APC and explains why $\mathrm{APC}^{\mathrm{Cdc} 20}$ has reduced ubiquitin ligase activity compared to $\mathrm{APC}^{\mathrm{Cdh} 1}$ (Fig. 3A). This may be due to species-specific differences between yeast Cdc20 and rabbit CCT. Alternatively, phosphorylation of Cdc20 or additional factors may be required for its efficient release from CCT and subsequent interaction with APC. Because Cdc20 does not appear to be processed properly, we perform most in vitro studies with Cdh1.

\section{APC-Substrate Interactions}

Similar to the APC-coactivator binding assay described earlier, APCsubstrate interactions can be examined using native gels (Passmore et al., 2003). The migration of ${ }^{35} \mathrm{~S}$-labeled APC substrates (Clb2 and a D- and KEN-box-containing domain of Hsl1, Hsl1 $\mathrm{p}^{667-872}$ ) changes upon the addition of APC and Cdh1 (Fig. 3B). Both APC and coactivator are required for this band shift. These bands represent APC-substrate complexes, as their migrations are retarded by the addition of APC antibodies (Fig. 3B, lanes 5, 6, 9, and 10). These interactions are specific and likely to be physiologically relevant because they are dependent on the presence of intact D- and/or KEN-boxes (Fig. 3B, lanes 11 and 12) (Passmore et al., 2003). 
APC-substrate-binding reactions are performed in $14 \mu \mathrm{l}$ with the following compositions:

$2 \mu \mathrm{l}$ purified APC ( $\sim 50 \mathrm{ng}$ ) or CaM elution buffer (Table I) for negative control

$2 \mu \mathrm{l}{ }^{35} \mathrm{~S}$-labeled substrate (produced in IVT as described earlier)

$2 \mu \mathrm{l}$ unlabeled coactivator (produced in IVT as described earlier) or mock IVT reaction for negative control

$0.7 \mu \mathrm{l} 100 \mathrm{~m} M \mathrm{CaCl}_{2}$

Adjust the volume to $14 \mu \mathrm{l}$ with binding buffer ( $10 \mathrm{~m} M$ Tris-Cl, $\mathrm{pH} 8.0$, $150 \mathrm{~m} M \mathrm{NaCl}, 3 \mathrm{~m} M$ DTT, $1 \mathrm{~m} M \mathrm{Mg}$-acetate, $2 \mathrm{~m} M$ EGTA). Incubate samples at room temperature for $15 \mathrm{~min}$, add $1.5 \mu \mathrm{l}$ native gel sample buffer, and load the entire reaction onto a $5.25 \%$ native gel.

We have been unable to detect interactions between APC and Pds1 in the native gel assay, presumably due to a lower affinity of $\mathrm{APC}^{\mathrm{Cdh} 1}$ for Pds1. In addition, the interaction of substrates with $\mathrm{APC}^{\mathrm{Cdc} 20}$ could not be detected, probably due to the poor processing of yeast $\mathrm{Cdc} 20$ by rabbit $\mathrm{CCT}$ as described previously. The $\mathrm{pH}$ of the native gels is high $(\mathrm{pH} 8.8)$, which may affect some protein-protein interactions negatively. However, our attempts to run native gels at lower $\mathrm{pH}$ have been unsuccessful.

\section{Antibody Shifts}

Antibodies to APC subunits induce an antibody shift (Fig. 3B), proving that the complexes visualized on native gels contain APC. For antibody shifts, prepare the binding reactions as described earlier, except make them up to $12 \mu \mathrm{l}$ instead of $14 \mu \mathrm{l}$. After all of the other components have been mixed together, add $2 \mu \mathrm{l}$ antibody and proceed as described earlier.

\section{Native Gel Composition}

We perform native gel analysis using the Mini-PROTEAN 3 system (Bio-Rad) with 1.5-mm spacers and 15-well combs. Prepare native gels using the following gel compositions (Liou and Willison, 1997):

Resolving gel: $0.37 M$ Tris, $\mathrm{pH}$ 8.8, 5.25\% 37.5:1 acrylamide:bisacrylamide

Stacking gel: $57 \mathrm{~m} M$ Tris, $\mathrm{pH}$ 8.8, 3.22\% 37.5:1 acrylamide:bisacrylamide

Running buffer: $25 \mathrm{~m} M$ Tris, $192 \mathrm{~m} M$ glycine, $\mathrm{pH} 8.3$ (to make a $10 \times$ stock solution, dissolve $30 \mathrm{~g}$ Tris base and $144.2 \mathrm{~g}$ glycine in 1 liter water) 
Native gel sample buffer: $125 \mathrm{~m} M$ Tris, $\mathrm{pH}$ 8.8, 84\% (v/v) glycerol, bromphenol blue to color

Both the resolving and the stacking gels are made using a 30\% acrylamide solution and a $1.5 \mathrm{M}$ Tris solution ( $\mathrm{pH} 8.8$ at room temperature). Chill native gels and running buffer to $4^{\circ}$ before use. Run gels at $110 \mathrm{~V}$ and $4^{\circ}$ for approximately $2 \mathrm{~h}$, until the dye front reaches the bottom of the gel. Fix, stain, and dry the gels as described previously and expose to BioMax MR-1 film.

\section{Deletion Strains}

The functions of individual APC subunits and their interactions within the complex are largely unknown. Because APC subunits are difficult to overexpress and purify, most of them cannot be studied in isolation. Five of the APC subunits are not essential for viability (DOC1, APC9, CDC26, $S W M 1$, and $M N D 2$ ) and therefore can be deleted in the CDC16-TAP yeast strain. Using these deletion strains, the TAP purification approach, the in vitro ubiquitination assay, and the APC-binding assay provide excellent tools to delineate the roles of individual APC subunits.

To construct deletion strains, we use PCR-based gene targeting (as described earlier) using the pAG32c vector (Goldstein and McCusker, 1999) instead of pFA6a-TAP-kanMX6. The pAG32c vector contains a hygromycin resistance marker and can be used to transform the CDC16$T A P$ strain, which already has G418 resistance (using $200 \mu \mathrm{g} / \mathrm{ml}$ hygromycin B and $300 \mu \mathrm{g} / \mathrm{ml} \mathrm{G} 418$ for selection). Strains with deleted APC subunits should be grown at $25^{\circ}$. Deletion of DOC1, CDC26, or SWM1 results in temperature sensitivity, and the $D O C 1$ deletion strain grows very slowly even at $25^{\circ}$. APC can be purified from the deletion strains to examine its stability, activity, and ability to interact with coactivators or substrates.

\section{Conclusion}

This chapter describes a TAP purification approach to purify endogenous $S$. cerevisiae APC to near homogeneity. In addition, we described an in vitro ubiquitination assay and an APC-binding assay. In the ubiquitination assay, the APC forms polyubiquitin chains on yeast substrates (Pds1, $\mathrm{Clb} 2$, and Hsl1), but only in the presence of one of the coactivators, Cdc20 or Cdh1. These coactivators confer substrate specificity upon the APC in a D-box and KEN-box-dependent manner, reflecting in vivo observations. The native gel APC-binding assay can be used to explore the properties of coactivator and substrate interactions with the APC. In this assay, the 
association of yeast APC substrates (Clb2 and Hs11) with the APC is dependent on coactivator and intact substrate D- and KEN-boxes. These properties reflect the in vivo requirements of APC-mediated ubiquitination reactions. Finally, we described how these techniques can be used to study the roles of individual APC subunits.

\section{Acknowledgments}

We thank E. A. McCormack and K. R. Willison for assistance in developing the native gel assays. This work is supported by NIH Grant AG11085 to J. W. H. and by Cancer Research UK to D. B.

\section{References}

Ansorge, W. (1985). Fast and sensitive detection of protein and DNA bands by treatment with potassium permanganate. J. Biochem. Biophys. Methods 11, 13-20.

Aristarkhov, A., Eytan, E., Moghe, A., Admon, A., Hershko, A., and Ruderman, J. V. (1996). E2-C, a cyclin-selective ubiquitin carrier protein required for the destruction of mitotic cyclins. Proc. Natl. Acad. Sci. USA 93, 4294-4299.

Blumenthal, D. K., Takio, K., Edelman, A. M., Charbonneau, H., Titani, K., Walsh, K. A., and Krebs, E. G. (1985). Identification of the calmodulin-binding domain of skeletal muscle myosin light chain kinase. Proc. Natl. Acad. Sci. USA 82, 3187-3191.

Bukau, B., and Horwich, A. L. (1998). The Hsp70 and Hsp60 chaperone machines. Cell 92, $351-366$.

Burton, J. L., and Solomon, M. J. (2001). D box and KEN box motifs in budding yeast Hsl1p are required for APC-mediated degradation and direct binding to Cdc20p and Cdh1p. Genes Dev. 15, 2381-2395.

Camasses, A., Bogdanova, A., Shevchenko, A., and Zachariae, W. (2003). The CCT chaperonin promotes activation of the anaphase-promoting complex through the generation of functional Cdc20. Mol. Cell 12, 87-100.

Carroll, C. W., and Morgan, D. O. (2002). The Doc1 subunit is a processivity factor for the anaphase-promoting complex. Nature Cell Biol. 4, 880-887.

Charles, J. F., Jaspersen, S. L., Tinker-Kulberg, R. L., Hwang, L., Szidon, A., and Morgan, D. O. (1998). The Polo-related kinase Cdc5 activates and is destroyed by the mitotic cyclin destruction machinery in S. cerevisiae. Curr. Biol. 8, 497-507.

Ciechanover, A., Elias, S., Heller, H., and Hershko, A. (1982). "Covalent affinity" purification of ubiquitin-activating enzyme. J. Biol. Chem. 257, 2537-2542.

Fang, G., Yu, H., and Kirschner, M. W. (1998). Direct binding of CDC20 protein family members activates the anaphase-promoting complex in mitosis and G1. Mol. Cell 2, $163-171$.

Garrels, J. I., McLaughlin, C. S., Warner, J. R., Futcher, B., Latter, G. I., Kobayashi, R., Schwender, B., Volpe, T., Anderson, D. S., Mesquita-Fuentes, R., and Payne, W. E. (1997). Proteome studies of Saccharomyces cerevisiae: Identification and characterization of abundant proteins. Electrophoresis 18, 1347-1360.

Gavin, A. C., Bösche, M., Krause, R., Grandi, P., Marzioch, M., Bauer, A., Schultz, J., Rick, J. M., Michon, A. M., Cruciat, C. M., Remor, M., Höfert, C., Schelder, M., Brajenovic, M., Ruffner, H., Merino, A., Klein, K., Hudak, M., Dickson, D., Rudi, T., et al. (2002). 
Functional organization of the yeast proteome by systematic analysis of protein complexes. Nature 415, 141-147.

Golan, A., Yudkovsky, Y., and Hershko, A. (2002). The cyclin-ubiquitin ligase activity of cyclosome/APC is jointly activated by protein kinases Cdk1-cyclin B and Plk. J. Biol. Chem. 277, 15552-15557.

Goldstein, A. L., and McCusker, J. H. (1999). Three new dominant drug resistance cassettes for gene disruption in Saccharomyces cerevisiae. Yeast 15, 1541-1553.

Haas, A. L., and Bright, P. M. (1988). The resolution and characterization of putative ubiquitin carrier protein isozymes from rabbit reticulocytes. J. Biol. Chem. 263, $13258-13267$.

Harlow, E., and Lane, D. (1999). "Using Antibodies: A Laboratory Manual." Cold Spring Harbor Laboratory Press, Cold Spring Harbor, NY.

Harper, J. W., Burton, J. L., and Solomon, M. J. (2002). The anaphase promoting complex: It's not just for mitosis anymore. Genes Dev. 16, 2179-2206.

Hendrickson, C., Meyn, M. A., 3rd, Morabito, L., and Holloway, S. L. (2001). The KEN box regulates $\mathrm{Clb} 2$ proteolysis in $\mathrm{G} 1$ and at the metaphase-to-anaphase transition. Curr. Biol. 11, 1781-1787.

Hershko, A., and Rose, I. A. (1987). Ubiquitin-aldehyde: A general inhibitor of ubiquitinrecycling processes. Proc. Natl. Acad. Sci. USA 84, 1829-1833.

Hilioti, Z., Chung, Y. S., Mochizuki, Y., Hardy, C. F., and Cohen-Fix, O. (2001). The anaphase inhibitor Pds1 binds to the APC/C-associated protein $\mathrm{Cdc} 20$ in a destruction boxdependent manner. Curr. Biol. 11, 1347-1352.

Ho, Y., Gruhler, A., Heilbut, A., Bader, G. D., Moore, L., Adams, S. L., Millar, A., Taylor, P., Bennett, K., Boutilier, K., Yang, L., Wolting, C., Donaldson, I., Schandorff, S., Shewnarane, J., Vo, M., Taggart, J., Goudreault, M., Muskat, B., Alfarano, C., et al. (2002). Systematic identification of protein complexes in Saccharomyces cerevisiae by mass spectrometry. Nature 415, 180-183.

Jones, E. W. (1977). Proteinase mutants of Saccharomyces cerevisiae. Genetics 85, 23-33.

Jones, E. W. (2002). Vacuolar proteases and proteolytic artifacts in Saccharomyces cerevisiae. Methods Enzymol. 351, 127-150.

King, R. W., Peters, J. M., Tugendreich, S., Rolfe, M., Hieter, P., and Kirschner, M. W. (1995). A 20 S complex containing CDC27 and CDC16 catalyzes the mitosis-specific conjugation of ubiquitin to cyclin B. Cell 81, 279-288.

Kotani, S., Tugendreich, S., Fujii, M., Jorgensen, P. M., Watanabe, N., Hoog, C., Hieter, P., and Todokoro, K. (1998). PKA and MPF-activated Polo-like kinase regulate anaphasepromoting complex activity and mitosis progression. Mol. Cell 1, 371-380.

Kramer, E. R., Scheuringer, N., Podtelejnikov, A. V., Mann, M., and Peters, J. M. (2000). Mitotic regulation of the APC activator proteins CDC20 and CDH1. Mol. Biol. Cell 11, $1555-1569$.

Liou, A. K., and Willison, K. R. (1997). Elucidation of the subunit orientation in CCT (chaperonin containing TCP1) from the subunit composition of CCT micro-complexes. EMBO J. 16, 4311-4316.

Melandri, F., Grenier, L., Plamondon, L., Huskey, W. P., and Stein, R. L. (1996). Kinetic studies on the inhibition of isopeptidase $\mathrm{T}$ by ubiquitin aldehyde. Biochemistry 35, 12893-12900.

Orlowski, M., Cardozo, C., and Michaud, C. (1993). Evidence for the presence of five distinct proteolytic components in the pituitary multicatalytic proteinase complex: Properties of two components cleaving bonds on the carboxyl side of branched chain and small neutral amino acids. Biochemistry 32, 1563-1572. 
Passmore, L. A. (2003). "Structural and Functional Studies of the Anaphase-Promoting Complex (APC)." Ph.D Thesis, University of London.

Passmore, L. A., McCormack, E. A., Au, S. W., Paul, A., Willison, K. R., Harper, J. W., and Barford, D. (2003). Doc1 mediates the activity of the anaphase-promoting complex by contributing to substrate recognition. EMBO J. 22, 786-796.

Peters, J. M. (2002). The anaphase-promoting complex: Proteolysis in mitosis and beyond. Mol. cell. 9, 931-943.

Pfleger, C. M., and Kirschner, M. W. (2000). The KEN box: An APC recognition signal distinct from the D box targeted by Cdh1. Genes Dev. 14, 655-665.

Pfleger, C. M., Lee, E., and Kirschner, M. W. (2001). Substrate recognition by the Cdc20 and Cdh1 components of the anaphase-promoting complex. Genes Dev. 15, 2396-2407.

Pickart, C. M., and Rose, I. A. (1986). Mechanism of ubiquitin carboxyl-terminal hydrolase: Borohydride and hydroxylamine inactivate in the presence of ubiquitin. J. Biol. Chem. 261, 10210-10217.

Prodromou, C., and Pearl, L. H. (1992). Recursive PCR: A novel technique for total gene synthesis. Protein Eng. 5, 827-829.

Puig, O., Caspary, F., Rigaut, G., Rutz, B., Bouveret, E., Bragado-Nilsson, E., Wilm, M., and Séraphin, B. (2001). The tandem affinity purification (TAP) method: A general procedure of protein complex purification. Methods 24, 218-229.

Rigaut, G., Shevchenko, A., Rutz, B., Wilm, M., Mann, M., and Séraphin, B. (1999). A generic protein purification method for protein complex characterization and proteome exploration. Nature Biotechnol. 17, 1030-1032.

Rudner, A. D., and Murray, A. W. (2000). Phosphorylation by Cdc28 activates the Cdc20-dependent activity of the anaphase-promoting complex. J. Cell Biol. 149, $1377-1390$.

Sambrook, J., and Russell, D. W. (2001). "Molecular Cloning: A Laboratory Manual," 3rd Ed. Cold Spring Harbor Laboratory Press, Cold Spring Harbor, NY.

Valpuesta, J. M., Martin-Beníto, J., Gómez-Puertas, P., Carrascosa, J. L., and Willison, K. R. (2002). Structure and function of a protein folding machine: The eukaryotic cytosolic chaperonin CCT. FEBS Lett. 529, 11-16.

Vinitsky, A., Michaud, C., Powers, J. C., and Orlowski, M. (1992). Inhibition of the chymotrypsin-like activity of the pituitary multicatalytic proteinase complex. Biochemistry 31, 9421-9428.

Visintin, R., Prinz, S., and Amon, A. (1997). $C D C 20$ and $C D H 1$ : A family of substrate-specific activators of APC-dependent proteolysis. Science 278, 460-463.

Wach, A., Brachat, A., Rebischung, C., Steiner, S., Pokorni, K., Hessen, S., and Philippsen, P. (1998). PCR-based gene targetting in Saccharomyces cerevisiae. In "Yeast Gene Analysis" (A. J. P. Brown and M. Tuite, eds.), Vol. 26, pp. 67-82. Academic Press, London.

Werner-Washburne, M., Braun, E., Johnston, G. C., and Singer, R. A. (1993). Stationary phase in the yeast Saccharomyces cerevisiae. Microbiol. Rev. 57, 383-401.

Zachariae, W., Schwab, M., Nasmyth, K., and Seufert, W. (1998a). Control of cyclin ubiquitination by CDK-regulated binding of Hct1 to the anaphase promoting complex. Science 282, 1721-1724.

Zachariae, W., Shevchenko, A., Andrews, P. D., Ciosk, R., Galova, M., Stark, M. J., Mann, M., and Nasmyth, K. (1998b). Mass spectrometric analysis of the anaphasepromoting complex from yeast: Identification of a subunit related to cullins. Science 279, $1216-1219$. 
Zachariae, W., Shin, T. H., Galova, M., Obermaier, B., and Nasmyth, K. (1996). Identification of subunits of the anaphase-promoting complex of Saccharomyces cerevisiae. Science 274, 1201-1204.

Zubenko, G. S., Mitchell, A. P., and Jones, E. W. (1980). Mapping of the proteinase b structural gene PRB1, in Saccharomyces cerevisiae and identification of nonsense alleles within the locus. Genetics 96, 137-146.

\title{
[18] Enzymology of the Anaphase-Promoting Complex By Christopher W. Carroll and David O. Morgan
}

\begin{abstract}
The anaphase-promoting complex (APC) is an ubiquitin-protein ligase that promotes mitotic progression by catalyzing the ubiquitination of numerous proteins, including securin and cyclin. Its complex subunit composition and extensive regulation make the APC an active subject of investigation for both cell biologists and enzymologists. This chapter describes a system for the reconstitution and quantitative analysis of APC activity from budding yeast in vitro. We focus in particular on the measurement of processive ubiquitination, which complements traditional analysis of the reaction rate as a means to elucidate the molecular details of substrate recognition and ubiquitination by the APC.
\end{abstract}

\section{Introduction}

The covalent modification of proteins with ubiquitin is a widespread regulatory mechanism in cell biology. In mitosis, ubiquitin-mediated proteolysis of securin (Pds1 in budding yeast) and mitotic cyclins is required for sister chromatid separation and mitotic exit. The ubiquitination of these proteins is catalyzed by an ubiquitin-protein ligase (or E3 enzyme) called the anaphase-promoting complex.

The APC is a structurally complex E3 containing at least 11-13 subunits, most of which are conserved from yeast to humans (Harper et al., 2002; Peters, 2002). Two subunits, Apc11 and Apc2, contain a RING-H2 domain and a cullin-homology domain, respectively, and are thought to comprise the catalytic core of the enzyme: they form a stable subcomplex, can bind an E2-ubiqutin conjugate, and are sufficient to catalyze some aspects of the ubiquitination reaction (Gmachl et al., 2000; Leverson et al., 2000; Tang et al., 2001). However, the Apc2/11 heterodimer lacks 